\title{
Public opinion and foreign policy in João Goulart's Brazil (1961-1964): Coherence between national and foreign policy perceptions?
}

\author{
Opinião pública e política externa no Brasil de João Goulart \\ (1961-1964): coerência entre percepções de políticas nacional \\ e internacional?
}

http://dx.doi.org/10.1590/0034-7329201500206

FELIPE PEREIRA LOUREIRO* FELICIANO DE SÁ GUIMARÃES**

ADRIANA SCHOR***

Rev. Bras. Polít. Int. 58 (2): 98-118 [2015]

\section{Introduction}

Scholars have been paying increasing attention to the relationship between public opinion and foreign policy in emergent democracies, following a long established academic tradition in the United States and Western Europe. ${ }^{1}$ Few studies rely on a broader historical perspective though. This narrows down significantly the set of comparisons that one can make, constraining the capacity to better understand foreign policymaking in developing countries, and to advance theories in a wider historical perspective. ${ }^{2}$

Recent studies on the relationship between public opinion and foreign policy have shown that citizens tend to have coherent opinions across broad political topics, such as redistributive, ideological, and foreign policy issues (Page and Bouton 2006; Aldrich et al. 2006; Holsti 2004). In other words, a voter who

\footnotetext{
* Universidade de São Paulo, Instituto de Relações Internacionais, São Paulo - SP, Brazil (felipeloureiro@usp.br).

** Universidade de São Paulo, Instituto de Relações Internacionais, São Paulo - SP, Brazil (felicianosa@usp.br).

*** Universidade de São Paulo, Instituto de Relaçóes Internacionais, São Paulo - SP, Brazil (aschor@usp.br).

1 Studies on emergent democracies, such as Brazil, India, Mexico, and Turkey, include Faria (2008); Gonzalez et al. (2013); Castillo et al. (2015); Kennedy and Dickenson (2012); and Kapur (2009). For a review of the literature focused on the developed world, particularly the United States, see Burstein (2003) and Holsti (2004, chs 1-3). For "emergent democracies", see Culp and Plagemann (2013).

2 Historical accounts on the role played by public opinion in the making of US and UK foreign policies in the twentieth century have contributed enormously for theory building in International Relations. See, for example, Fenton (2012), Kusnitz (1984), Thompson (2010) and Wilkinson (2000).
} 
favors liberal policies in the domestic arena will likely support similar foreign policy actions. This is why scholars interested in understanding the role of public opinion in foreign policy focus on how coherent is the perception between domestic and foreign policy issues among citizens. This paper seeks to do the same taking João Goulart's Brazil (1961-1964) as case study.

Widely acknowledged as one of the main emerging democracies of the world, Brazil is an interesting case for an historical analysis (Whitehead 2002). In particular, the Goulart administration is a crucial period of the short-lived Brazilian postwar democracy (1946-1964). Scholars point out that the Goulart government was marked by unprecedented social unrest and intense popular participation in the public arena (Ferreira and Gomes 2014; Reis Filho 2014). The period was also a critical moment for Brazil's foreign policy. The Brazilian government moved away from a closer relationship with the United States and advocated a more neutralist role in the Cold War, particularly in the Western hemisphere (Storrs 1973).

Recent works on public opinion in Goulart's Brazil have shown high public support for socio-economic redistributive policies, such as agrarian and tax reforms (Ferreira and Gomes 2014; Motta 2014). However, the opinion polls used in these studies, conducted by the Brazilian Institute of Public Opinion and Statistics (Instituto Brasileiro de Opiniáo Pública e Estatística, IBOPE), present two limitations. First, they were restricted to few cities - normally São Paulo or the state of Guanabara (currently the city of Rio de Janeiro), biasing the results in favor of urban and more politicized voters. Second, they have no data on how Brazilian citizens perceived the country's foreign policy.

In contrast, we employ a recently declassified national urban opinion poll conducted in late 1962 by the Institute for Social and Economic Studies (Instituto de Estudos Sociais e Econômicos, INESE) on behalf of the United States Information Agency (USIA). ${ }^{3}$ This poll was conducted in all Brazilian cities with more than 10,000 habitants. It also contains some results for the same questions relative to 1961, which allows comparisons. Unfortunately, we were unable to find either the original 1961 survey or the microdata for the 1962 opinion poll, limiting our attempts to draw strong conclusions on the links between domestic and foreign policy preferences. We try to overcome these limitations by cross referencing the survey with other primary sources, and measuring the overlap coefficients of answers across domestic and foreign policy issues. The available results brings precious insight into Brazilian public opinion in the early 1960s. Moreover, this is possibly the only source known up to this day that displays public opinion data not only on socio-economic issues, but also on foreign policy initiatives.

Two research questions inform this study. To what extent did the Brazilian people support redistributive domestic policies, particularly agrarian and tax

3 Report, 'The Economic and Political Climate of Opinion in Latin America, and Attitudes Toward the Alliance for Progress', June 1963, Folder Latin America, General, 7/63-11/63, Box 216, National Security Files (hereafter NSF), John F. Kennedy Library (hereafter JFKL). 
reforms, as recent works on public opinion in Goulart's Brazil have sustained? In case of a positive answer, was there any coherence between such support and specific foreign policies strategies? In other words, to what extent did voters who favored redistributive reforms also support, for example, a foreign policy recognized as leftist, such as a nationalistic and anti-US foreign approaches?

One expects to see, mutatis mutandis, coherency between domestic and foreign policy perceptions. Taking the context of the early 1960s Latin America into consideration, it means "redistributive" supporters leaning towards Third World or Communist countries in world affairs. Contrarily, "non-redistributive" believers should support foreign policy preferences representing alignment with the United States.

Overall, we found that public opinion in Goulart's Brazil was somewhat coherent. The Brazilian society was, in its majority, not only supportive of "redistributive" policies, but also in favor of an "autonomous" foreign policy approach. However, the picture is not as clear as it might seem: the United States enjoyed a good image in Brazil (while Communist countries presented a bad one), and the number of Brazilians who supported a pro-US foreign policy was rapidly increasing in the early 1960s. This suggests that the Brazilian public opinion could be leaning towards incoherence on the eve of the 1964 military coup.

This paper has four sections. Section one analyses the literature on public opinion and foreign policy, and presents the methodology to measure coherence. Section two examines the historical context of the Goulart administration. Section three analyses the data of the INESE-USIA opinion pool, comparing its results on domestic policies to those related to Brazilian foreign policy and to the international system. The last section presents the conclusions.

\section{Literature and methodology}

The dominant consensus on the relationship between foreign policy and public opinion has evolved over time. The first wave of studies showed that public opinion was not coherent on foreign policy issues. Studies have focused on the stability or volatility of foreign policy perceptions, the level of knowledge about foreign policy, and, more importantly, the coherence of belief structures between domestic and foreign issues. In this regard, the idea was that voters did not have a structured and stable framework of beliefs and interpretation on foreign policy (Almond 1950; Verba et al. 1967).

A second wave of studies partially changed these notions. Scholars argued that collective behavior was to some extents coherent on foreign policy issues (Holsti 2004; Delli-Carpini and Keeter 1996; Popkin 1994). Yet, it still prevailed the perspective that voters knew almost nothing about international politics, or that the general public was unable to analyze complex international issues (Zaller 1992; Jacobs and Shapiro 2000). 
Recently, however, researchers have shown that public opinion is relatively stable and consistent in foreign policy perceptions across domestic and foreign issues. The general idea is that voters are able to develop and hold fairly coherent and structured views on foreign policy (Aldrich et al.1989; Aldrich et al. 2006). Page and Bouton (2006) argue that such change in the understanding is due to a revolution in the cognitive sciences - that is, an overhaul on the scientific understanding of how citizens receive, retain, and organize political information, as well as on the degree of responsiveness to leaders preferences (Iyengar and Kinder 1987; Krosnick and Kinder 1990; Sniderman 1993).

In this sense, al though citizens are almost always in disadvantage compared to political leaders and the media in terms of supply of information on international politics, they tend to overcome this limitation by employing heuristics shortcuts that allow them to make judgment about complex international issues (Baum and Potter 2008). The literature shows two mechanisms through which citizens are able to form their opinions: the first one is their traditional moral beliefs; the second is their general positions or normative beliefs. Due to the lack of systematic knowledge on issues of international relations, regular citizens use their more accessible values and normative stances - usually related to domestic issues - as source of information. They combine these two mechanisms with learning and information from past experiences, daily life, media, and political campaign in order to decide over international issues (Hurwitz and Peffley 1987; Popkin 1994). In other words, by using shortcuts, even a low-informed citizen would behave very similarly to a well-informed citizen (Castillo et al. 2015).

Turning to Brazilian literature, the idea that citizens can be influenced by foreign policy considerations when voting, or that they can structure broad political views on foreign policy issues using domestic policy perceptions, is almost nonexistent. The general perspective is that Brazilian voters are either not interested or not capable of organizing structured political views about foreign policy. The reasons for such behavior range from lack of interest and low political participation to isolated foreign policy formulation (Albuquerque et al. 1999; Manzur 1999; Holzhacker 2006; Almeida et al. 2012; Bressian 2012; Souza 2002; Souza 2008). Actually, Brazilian studies are more concerned about how organized groups and the media influence foreign policy (supposedly monopolized by Itamaraty, Brazil's Foreign Ministry) than to properly access what is the electoral connection between international politics and voters (Casaróes 2012; Lessa and Gaviáo 2011; Faria 2008 and 2012).

Furthermore, we have found no studies on how Brazilian citizens in the 1960s perceived foreign policy issues, or to what extent their perceptions were coherent to broader themes such as redistributive policies. ${ }^{4}$ Scholars who directly analyzed

4 The only study on the role of public opinion in Goulart's Brazil foreign policy focuses more on newspapers and the Legislative than public opinion per se. See Manzur (2009). 
Brazilian public opinion in the 1960s emphasized on domestic issues (land and tax reforms, for example) rather than on foreign policy aspects, due to the kind of questions posed by available surveys (Motta 2014).

To answer our questions, we look at the 1962 Brazilian public opinion survey through two axes related to domestic and foreign policy issues. First, we suggest a redistributive/non-redistributive axis for domestic perceptions. Although scholars generally analyze coherence taking partisanship, ideology and foreign policy opinion as main variables, our survey does not show data on party or ideological preferences, but only on redistributive issues. ${ }^{5}$ We understand redistributive policies as those pursued through taxation, property expropriations, or social expenditure and transfers. They are concerned with changing the existing allocation of resources within the society, favoring the poorest (Lowi 1972).

In this axis, we arranged public opinions perceptions on domestic reforms as either "redistributive" or "non-redistributive". "Redistributive" refers to those who defend land reform and nationalization of foreign companies without proper or full compensation to owners, as well as a progressive tax overhaul (wealthier paying more taxes than the poor). Conversely, "non-redistributive" refers to those who argue for no reforms at all (e.g., pro-status quo). Even though one could argue that citizens who stood up for land reform and nationalization of foreign companies with full compensation should have been interpreted as "non-redistributive", the redistributive impacts of such policies would have been significant, as it meant that the State would compel owners to abdicate their properties on the society's behalf.

Second, we suggest an autonomist/alignment axis for foreign policy perceptions. In general, the literature on how foreign policy opinion is structured defines three types of voters' attitudes towards foreign policy: militant internationalist policies (unilateralism and use of force), cooperative internationalist policies (active multilateralism), and isolationism (Hurwitz and Peffley 1987; Nau and Baum 2012). However, these types of attitudes are closely related to US foreign policy and not to the context of developing countries. The Brazilian foreign policy cannot be framed in these terms.

The debate about Brazil's foreign policy decisions gravitates around two conceptual frameworks: alignment versus autonomy. Alignment represents strategic proximity to the United States in regional and international fora. Broadly speaking, it means a soft bandwagoning line through closer relations with Washington. On the other hand, an autonomous approach means to distance Brazil from the Unites States via soft balancing strategies, usually seeking closer links to either defiant global powers or Third World coalitions (Lima 1994; Vigeviani and Cepaluni 2007; and Hirst 2013).

As the Brazilian literature on public opinion coherence is still in its early stages, the controversial and polarized political context of early 1960s' Brazil is

5 See Holsti (2004), Kull (2007), Nau and Baum (2012), and Page and Bouton (2006). 
an interesting starting point to test the argument. However, coherence is context dependent. The meaning of coherence in one scenario can be different from that on another one. In this sense, to understand the terms of the INESE-USIA survey, it is necessary to look at the debates on domestic and foreign policies taking place in Brazil in the early 1960s. Next section addresses this issue.

\section{Public policy and the Goulart administration in Brazil (1961-1962)}

The early 1960s was a watershed in Brazil's history. After years of intense economic growth, the country was facing severe constraints, such as rising inflation and deficits in the balance of payment (Abreu 2008). Implementing harsh economic stabilization programs triggered social unrest mainly in urban areas, where unionized labor initiated demonstrations and strikes. Workers struggled to avoid having the burden on their shoulders, whether through wage constraints or tax increases (Loureiro 2016). The level of social unrest in rural areas was also unprecedented, particularly in the Northeast, Brazil's most underdeveloped region. The fight for land and the extension of labor rights to the countryside were the main grievances raised. Brazil was facing an intense redistributive struggle (Welch 1999).

Economic and social instability translated into the political arena. In August 1961, the recently inaugurated President Jânio Quadros resigned, opening a serious political crisis. Vice-President João Goulart was impeded to step in, due to a faction of the military, who regarded him with suspicion. Goulart was the leader of the Brazilian Labor Party (Partido Trabalhista Brasileiro, PTB), and longtime protégé of Getúlio Vargas, a former Brazilian president and dictator. The right-wing of the military disregarded Goulart due to his close links with unionized labor, including Communist-led unions. A legalist movement arose though, and it was prepared to take up arms. To avoid a civil war, the Parliament decided to vote an amendment to the 1946 Constitution, setting up a parliamentary regime. It was also agreed that in mid-1965 the Brazilian people would decide whether the parliamentary system should continue (Labaki 1986). However, Goulart managed to anticipate this plebiscite to January 1963, when a large majority (82\%) voted for restoring his powers. In spite of this, socio-economic and political instability kept increasing, leading to Goulart's overthrow in March 1964 by a military coup (Skidmore 2007).

Goulart's rise to power in September 1961, even though constrained by a parliamentary straitjacket, did not avert him to bring forth his political agenda. The president defended the so-called "basic reforms" (reformas de base), e.g., a series of proposals focused on creating a new development framework, and meeting social demands for greater equality in property and income (Ferreira 2012). Among several issues the ones which stood out sere the proposals for agrarian and tax reforms, aimed at addressing problems still acute in Brazil to this day. Land distribution was very unequal, with few landowners holding the best and largest rural properties, while the majority of Brazilian peasants were landless. 
The Brazilian tax structure was also socially unfair, as taxation over consumption instead of property and income was predominant. This type of tax system favored wealthier citizens, stimulating income concentration (Loureiro 2012). Goulart and some leftist groups defended an agrarian reform in which landowners would be compensated according to the value employed for land taxation, and not to the (higher) market value of the land. Also, landowners would receive compensations not in money, but in long-term bonds. Of course this was strongly opposed by the rural elites, who saw these proposals as outright expropriation. As to the tax reform, Goulart planned to make a complete overhaul in the tax system, increasing direct taxes (income and property taxes), and relaxing tolls on consumption (Bandeira 2010; Skidmore, 2007).

A heated debate was also taking place as to how to proceed with foreign companies which invested in public utilities. These firms were criticized due to the low-quality services offered and lack of investments. The companies, on the other hand, complained they could not invest properly because of official control on tariffs. Expropriations pursued in the state of Rio Grande do Sul in 1959 and 1962 by Goulart's brother-in-law, governor Leonel Brizola, a radical leftist nationalist, triggered the debate. Brizola confiscated subsidiaries of two US companies in Rio Grande do Sul (the American Foreign and Power, AMFORP, and the International Telephone and Telegraph, ITT), respectively, paying token compensations in return. The companies complained bitterly, and, as Brazil needed US foreign aid, Goulart attempted to make a compromise, but pulled back (except for ITT) after strong domestic criticisms. In the end, AMFORP's expropriation would be settled only by the military regime in 1964 (Saes and Loureiro 2014).

Goulart also maintained a fundamental shift in direction of Brazil's foreign policy, which had started in the short-lived Quadros administration. The so-called "Independent Foreign Policy" of President Quadros (Politica Externa Independente, PEI) was based on the principle that the West-East divide could not be the main guideline for Brazil's international insertion. Instead, what should fulfill this role was the increasing North-South socio-economic gap. Even though Brazil did not present itself as neutralist or non-aligned, the country did sustain the pursuit of diplomatic relations pragmatically, focusing on how they could foster economic development, and not grounded on ideological divisions. It meant, for instance, that Brazil should be open to trade with and to receive investment from communist countries, and not to align automatically with the United States. Besides, PEI claimed the need to respect other nations' right for self-determination. In practice, Brazil would support the struggle for independence in Asia and Africa (a support that was also made pragmatically, as this could bring new markets), and sustain the principle of non-intervention in international relations (Storrs 1973; Vizentini 1995; Resende 2009).

The Quadros and Goulart governments pursued concrete actions to implement the Independent Foreign Policy. In May 1961, President Quadros 
sent a diplomatic mission to several Eastern European countries to settle trade agreements, and ended up with accords that increased enormously the prospect of trade with the Soviet bloc (Hershberg 2015). In November 1961, after thirteen years without formal contacts, Brazil and the Soviet Union resumed diplomatic relations. In January 1962, Foreign Minister Santiago Dantas led a group of Latin American nations at the Punta del Este Conference, held in Uruguay, against the US initiative to expel Cuba from the Organization of the American States (OAS) (Weis 2001). And, finally, during the Cuban Missile Crisis in October 1962, despite the fact that Brazil supported the US quarantine against Cuba, the Goulart government did not vote at the OAS meeting in favor of measures to allow Washington to employ force if necessary against the island (Hershberg 2004). Scholars agree that the turn of Brazil's foreign policy was important to deteriorate US-Brazilian relations (Weis 2001; Rabe 2012; Loureiro 2014).

Therefore, it was in this context of intense social struggles, support for basic reforms, and ruptures in the country's foreign policy that the INESE conducted its survey in late 1962. At that time, Brazilians had just left the ballot box of the October 1962 general election, choosing representatives for the National Congress, and for half of the state governors and local legislators. In January 1963, Brazilians would vote again - this time for the plebiscite to decide over the future of the parliamentary regime (Skidmore 2007). Hence, there was hardly a better time to assess the citizens' opinion on domestic issues, as these were strongly explored in public campaigns and in the media. Foreign policy issues were also on the spot due to the Cuban Missile Crisis. In the lights of this favorable context, one needs to ask: what were Brazilians' views on domestic and foreign issues? Were they coherent or incongruent? Next section addresses these points.

\section{The 1962 INESE-USIA survey and data analysis}

The report of the 1961-1962 Brazilian opinion survey conducted on behalf of the USIA was based on a sample of 1,593 (1961 survey) and 1,327 individuals (1962 survey). Unfortunately, it does not discuss methodological procedures. The report only points out that the results were "based primarily on area probability samples of adults in urban areas" (cities of 10,000 inhabitants or over), and that the questionnaire was produced by USIA's Survey Research Division, having the field work conducted by the Institute for Social and Economic Studies (INESE). The INESE had already made other surveys for the USIA. The institute was chosen exactly because it constituted, according to the USIA, an "established, professional research organization". ${ }^{6}$

6 Report, 'The Economic and Political Climate of Opinion', Box 216, NSF, JFKL, p. iv. As an example of another public opinion survey conducted by INESE on behalf of the USIA, see Report, 'Brazil in Crisis Attitudes', Sept. 1961, Box 11, Country Project Files, compiled ca. 1953 - 1965 (hereafter CPF), Record Group (hereafter RG) 306, National Archives and Records Administration, College Park (hereafter NARA). 
Brazilians were interviewed on several economic and political issues, related to domestic and international topics. All aggregate results were presented in percentage points. Questions that referred to domestic issues were mainly focused on mapping out the opinion regarding the country's economic conditions and the support for reforms proposed by the Goulart administration. The main character of these reforms, as discussed above, was to redistribute wealth (through land reform and nationalization of foreign capital) and income (through a tax reform).

A first set of questions of the 1962 survey attempts to access public opinion on what changes should take place in Brazil's economy and society. There were formulated as open-ended questions, which means interviewers had freedom to elaborate multiple word answers, and not only to choose between "yes" or "no" (closed-ended questions). Around 20\% of those interviewed pointed out that an agrarian reform was necessary. Other alternatives, ranging from changes in education and housing policies to radical transformations in the economic system, represented together less than $10 \%$ of the answers - with the exception of "reducing the cost of living", mentioned by $15 \%$. It should be noted that $44 \%$ of those interviewed did not have opinion, did not answer, or believed that no reforms were needed, which is a very significant result. The great number of urban Brazilians who did not know or did not have a position on central public issues could probably be seen as a consequence of the country's high illiteracy rates $37 \%$ in 1965) - above that of Latin America's average (32\%) (Wattles 1966, 3).

The second question reported asked what Brazilians thought about "a land reform that would divide the large agricultural properties and distribute the land among agricultural workers". As Table 1 shows, $68 \%$ of those interviewed in 1962 supported land reform (a 11.5\% increase in relation to 1961). Among these, roughly $42.6 \%$ argued that landowners should receive the full worth for their properties as compensation, while almost the same proportion (41.2\%) were in favor of more leftist-oriented reforms: landowners were either to receive only partially (33.8\%) for their properties, or to get no compensation at all (7.4\%). Broadly speaking, results for 1961 and 1962 present similar patterns, with just a minor inversion: while in 1961 stronger leftist reformists slightly prevailed (44.3\%), in 1962 moderates were in a slender advantage.

Taking into account those who opposed any type of land reform (11\% of the total sample in 1961, and 8\% in 1962), one reaches the conclusion that the majority of Brazilians had some respect for property rights (at least when it comes to land tenure), either by means of full worth payment to landowners, or by simply allowing owners to keep their lands. However, as the redistributive impacts of even a moderate land reform would still be significant, we classify Brazilian public opinion on land reform as "redistributive" - a trend strengthened in 1962. 
Table 1. Brazilian Public Opinion on Land Reform, Nationalization of Foreign-owned Companies, and Tax Reform, \% (1961-1962)

\begin{tabular}{|c|c|c|c|c|c|}
\hline \multirow[b]{2}{*}{ General position } & \multicolumn{2}{|c|}{ Land Reform } & \multicolumn{2}{|c|}{$\begin{array}{l}\text { Nationalization of } \\
\text { Foreign-owned Companies }\end{array}$} & \multirow{2}{*}{$\begin{array}{c}\begin{array}{c}\text { Tax } \\
\text { Reform }\end{array} \\
1962\end{array}$} \\
\hline & 1961 & 1962 & 1961 & 1962 & \\
\hline Favor & 61,0 & 68,0 & 16,0 & 36,0 & 56,0 \\
\hline Oppose & 11,0 & 8,0 & 57,0 & 31,0 & 16,0 \\
\hline Don't care & - & 8,0 & - & - & 12,0 \\
\hline No opinion & 28,0 & 16,0 & 27,0 & 33,0 & 16,0 \\
\hline Total & 100,0 & 100,0 & 100,0 & 100,0 & 100,0 \\
\hline Type of Compensation* & 1961 & 1962 & 1961 & 1962 & 1962 \\
\hline Full worth & 42,6 & 42,6 & 31,3 & 44,4 & - \\
\hline Part worth & 34,4 & 33,8 & 37,5 & 36,1 & - \\
\hline Nothing at all & 9,8 & 7,4 & 18,8 & 8,3 & - \\
\hline No opinion & 13,1 & 16,2 & 12,5 & 11,1 & - \\
\hline Total & 100,0 & 100,0 & 100,0 & 100,0 & - \\
\hline Number of interviewers & 1.593 & 1.327 & 1.593 & 1.327 & 1.327 \\
\hline
\end{tabular}

Source: Report, 'The Economic and Political Climate of Opinion', Box 216, NSF, JFKL.

Note: * Among those who favored land reform (61.0\% and 68.0\% of the total in 1961 and 1962, respectively) or nationalization of foreign-owned companies (16.0\% and 36.0\% of the total in 1961 and 1962, respectively).

A similar picture emerges when one looks at opinions on tax reform (Table 1). The survey questioned whether Brazilians supported a change in legislation to build a progressive tax structure - this is to say, to create a tax system "which could make the better-off pay higher taxes". The great majority (56\%) pointed out they favored a redistributive tax reform, while only $16 \%$ defended the status quo. The remaining $28 \%$ did not care, or did not have opinion about it, which is also a high rate, even though significantly lower than the $44 \%$ one finds in open-ended questions. Thus, with regards to tax reform, Brazilian public opinion may also be ordered as "redistributive".

Turning to the nationalization of foreign-owned companies, another much-debated issue in Goulart's Brazil, one finds an extremely complex situation (Table 1). There was a major turn of opinion during the first two years of the Goulart administration. While in 1961 the absolute majority of Brazilians (51\%) opposed nationalization of foreign industries, in 1962 the picture evolved into a stalemate: roughly one-third of those interviewed either favored, opposed or did not have an opinion on the issue, with a slight advantage for those who argued 
for nationalization (36\%). Among these, there was a standoff between those who wanted foreign companies to receive full-worth for their properties $(44.4 \%)$, and those who either advocated the payment of part-worth compensations $(36.1 \%)$ or no compensation at all (8.3\%). Therefore, we classify the Brazilian public opinion in this regard as slight "redistributive".

In sum, the data shows a fairly coherent picture of the Brazilian public opinion during the Goulart administration, at least when looking at domestic issues. If it is clear that there were many Brazilians who preferred moderate, and not radical, socio-economic changes (land reform and nationalization of foreign companies with full compensation to owners, for instance); on the other hand, it is also evident that the majority wished for some type of redistributive reform. Adding moderate reformers to those who stood up for radical changes, one reaches the conclusion that a "redistributive" position predominated in domestic topics, and it was increasingly gaining ground.

The second part of the report presents results on international issues. First, Brazilians were asked about how they perceived Cold War superpowers (the United States and the Soviet Union), as well as the leader of the 1959 Cuban Revolution, Fidel Castro (Table 2). The data is clear in showing that Brazilians didn't perceive either Fidel or the Soviet Union in a positive light. Among those who did answer the question (roughly $60 \%$ of the total), the absolute majority had either a "bad" or a "very bad opinion" about Fidel Castro and the Soviet Union. Interestingly, the perceptions on Fidel Castro deteriorated sharply between those two years. While in 1961 half (50\%) of the Brazilians presented a "bad" or a "very bad opinion" on Castro, in 1962 this proportion jumped to almost 70\%. Probably the fact Castro announced the Communist character of the 1959 Revolution in late 1961, and that Cuba and the USSR deepened their alliance in 1962, leading to the Cuban Missile Crisis, might explain this deterioration.

When it comes to the US image in Brazil, the situation is reversed. The large majority of Brazilians held the United States in high regard, and such proportion increased during the two first years of Goulart's term. Among those who did have a stand on the United States (roughly 70\% of total respondents), 63.6\% in 1961 and 69.4\% in 1962 presented either a "good" or a "very good opinion" about Washington. Similarly striking, the proportion of people who did not have an opinion about the United States was not only lower than the Soviet Union, but also decreased in comparison to 1961 (34\% to 28\%). Definitely, Brazilians had a pro-US stance in the Cold War. According to our foreign policy axis, these rates show an "alignment" outlook. 
Table 2. Brazilian Public Opinion on Fidel Castro, Soviet Union, and United States, \% (1961-1962)

\begin{tabular}{|l|c|c|c|c|c|}
\hline General position & $\mathbf{1 9 6 1}$ & $\mathbf{1 9 6 2}$ & $\mathbf{1 9 6 2}$ & $\mathbf{1 9 6 1}$ & $\mathbf{1 9 6 2}$ \\
\hline 1. Very good opinion & 2,0 & 1,0 & 2,0 & 10,0 & 14,0 \\
\hline 2. Good opinion & 10,0 & 7,0 & 10,0 & 32,0 & 36,0 \\
\hline 3. Neither good nor bad & 16,0 & 12,0 & 16,0 & 20,0 & 18,0 \\
\hline 4. Bad opinion & 9,0 & 25,0 & 23,0 & 1,0 & 3,0 \\
\hline 5. Very bad opinion & 19,0 & 20,0 & 12,0 & 3,0 & 1,0 \\
\hline No opinion & 25,0 & 18,0 & 37,0 & 34,0 & 28,0 \\
\hline Not asked* & 19,0 & 17,0 & - & - & - \\
\hline Total & 100,0 & 100,0 & 100,0 & 100,0 & 100,0 \\
\hline Those with opinion** & $\mathbf{1 9 6 1}$ & $\mathbf{1 9 6 2}$ & $\mathbf{1 9 6 2}$ & $\mathbf{1 9 6 1}$ & $\mathbf{1 9 6 2}$ \\
\hline Good (1-2) & 21,4 & 12,3 & 19,0 & 63,6 & 69,4 \\
\hline Neither good nor bad (3) & 28,6 & 18,5 & 25,4 & 30,3 & 25,0 \\
\hline Bad (4-5) & 50,0 & 69,2 & 55,6 & 6,1 & 5,6 \\
\hline Number of interviewers & 1.593 & 1.327 & 1.327 & 1.593 & 1.327 \\
\hline
\end{tabular}

Source: Report, 'The Economic and Political Climate of Opinion', Box 216, NSF, JFKL.

Notes: ${ }^{*}$ Not asked because they have never heard of Castro; ${ }^{* *}$ Of those who expressed opinion on Fidel Castro (56\% and 65\% of the total in 1961 and 1962, respectively), the Soviet Union (63\% of the total in 1962), and the United States (66\% and $72 \%$ of the total in 1961 and 1962, respectively).

This large favorable perception of the United States among Brazilians, however, did not translate into a broad support of alignment with the West (Table 3). Although 45\% of the respondents in 1962 said they had very great or considerable confidence "in the ability of the United States to provide wise leadership for other countries in dealing with present world problems", only $30 \%$ in 1961, and 37\% in 1962 favored an alliance with Washington in international affairs. If we exclude those that did not have a position (roughly a quarter of total respondents), the picture is not altered significantly. Indeed, a pro-US foreign policy stance had a large support among the population with opinion, and this support was increasing (from $39,5 \%$ to $48,1 \%$ ). However, it still lagged a little behind those that favored a neutralist approach in foreign affairs $(56,6 \%$ in 1961 , and 50,6\% in 1962). This suggests, albeit slightly, a more "autonomist" approach. 
Table 3. Brazilian Public Opinion on the Orientation of the Country's Foreign Policy, \% (1961-1962)

\begin{tabular}{|l|c|c|}
\hline Brazil should side with & $\mathbf{1 9 6 1}$ & $\mathbf{1 9 6 2}$ \\
\hline United States & 30,0 & 37,0 \\
\hline Russia & 3,0 & 1,0 \\
\hline Neither & 43,0 & 39,0 \\
\hline No opinion & 24,0 & 23,0 \\
\hline Total & 100,0 & 100,0 \\
\hline Those with opinion* & $\mathbf{1 9 6 1}$ & $\mathbf{1 9 6 2}$ \\
\hline United States & 39,5 & 48,1 \\
\hline Russia & 3,9 & 1,3 \\
\hline Neither & 56,6 & 50,6 \\
\hline Total & 100,0 & 100,0 \\
\hline Number of interviewers & $\mathbf{1 . 5 9 3}$ & $\mathbf{1 . 3 2 7}$ \\
\hline
\end{tabular}

Source: Report, 'The Economic and Political Climate of Opinion', Box 216, NSF, JFKL.

Notes: * Of those who expressed opinion on the orientation of Brazil's foreign policy, e.g., pro-United States (30\% and 37\% of the total in 1961 and 1962, respectively), pro-Soviet Union (3\% and 1\% of the total in 1961 and 1962, respectively), and neither countries ( $43 \%$ and $39 \%$ of the total in 1961 and 1962, respectively).

Is it possible to argue that these numbers show an incoherent Brazilian public opinion? We believe there are elements that suggest otherwise. Two aspects in particular may explain why the United States enjoyed a good image among Brazilians, even though the majority of the country's citizens defended redistributive domestic policies, and a slight majority argued for a neutralist foreign policy approach. First, most citizens stood up for property rights, that is, many advocated either the implementation of moderate structural reforms (reforms that embodied a full-worth compensation to property owners), or the maintenance of the status quo (no reforms at all). This is coherent with positions that expressed admiration for the United States and disapproval of communist countries. Second, in the early 1960s, Brazilian policymakers presented the country's "Independent Foreign Policy" (PEI) not as anti-US or anti-West. In fact, the PEI was defended as a pragmatic - and, thus, supposedly non-ideological - response to Brazil's dire economic strains. Even though Brazil continued to uphold Western values and to belong to the West, it needed to expand relations worldwide to foster economic development (Storrs 1973; Vizentini 1995). In this sense, it is not incoherent that most Brazilians had Washington in high esteem and, at the same time, a slight majority supported a neutral (e.g., pragmatic) approach in foreign affairs. 
A more difficult issue relates to the fact that the lack of the survey's microdata makes it harder to state whether a given Brazilian "reformist" was also supportive of an "autonomous" foreign approach, and vice-versa. However, there are ways to circumscribe this limitation (but not to overcome it). For each one of the selected domestic variables, we calculated the overlap coefficient in relation to the group of Brazilians who favored an "autonomous" foreign policy in 1961 and 1962. ${ }^{7}$ To find out the intersection between a given pair of variables, we developed two distinct scenarios: a worst-case scenario, in which we assumed that all of those with "no opinion" never overlapped; and a best-case scenario, in which we supposed that "no opinion" respondents overlapped perfectly (always taking the lower proportion of "no opinion" respondents as guideline). In other words, our worst-case and best-case scenarios worked, respectively, as low and high limits of the overlapping area of a given pair of variables.

As can be seen in Table 4, in the worst-case scenario, none of the respondents who supported an autonomist foreign approach argued for a redistributive tax reform or for the nationalization of foreign firms, and only 4\% and 17.8\% (in 1961 and 1962, respectively) defended an agrarian reform. On the other hand, in the best-case scenario, only supporters of the nationalization of foreign firms did not overlap with "autonomists" at all. In the remaining cases, the overlap coefficient ranged from a low of 0.48 (tax reform) to a high of 0.76 (agrarian reform in 1962).

The pair agrarian reform/autonomous foreign policy shows that between $17.8 \%$ and $76 \%$ of "autonomists" Brazilians in 1962 also supported agrarian reform. Although one could argue that the actual overlapping might have been something in between (47.5\%), it is reasonable to expect that support was closer to the best-case than to the worst-case scenario due to the existence of heuristic shortcuts used by voters. That is, these shortcuts have probably reinforced overlapping perceptions because an individual's interpretation of policy issues usually depends on preexisting belief systems and media cues - in this case the domestic debate promoted by the government about redistributive reforms in Brazil. In other words, if a given Brazilian did not have opinion on redistributive domestic issues, the probability that this same person would also have no opinion on (more distant and complicated) international issues was high, thus making the real overlap coefficient large.

7 The overlap coefficient of a pair of variables $(\mathrm{X}, \mathrm{Y})$ is calculated by dividing the size of the intersection between these variables by the size of the smaller variable. See the formula employed on Table 4. 
Table 4. Brazil's Public Opinion Overlap Coefficients for Redistributive Domestic Policies and Autonomous Foreign Policy (1961-1962)†

\begin{tabular}{|l|c|c|c|c|}
\hline & \multicolumn{2}{|c|}{ Worst case* $^{*}$} & \multicolumn{2}{c|}{ Best case** $^{*}$} \\
\hline Land Reform and Autonomy & $\mathbf{1 9 6 1}$ & $\mathbf{1 9 6 2}$ & $\mathbf{1 9 6 1}$ & $\mathbf{1 9 6 2}$ \\
\hline Tax Reform and Autonomy & 0,09 & 0,18 & 0,65 & 0,77 \\
\hline Nationalization and Autonomy & - & 0,00 & - & 0,46 \\
\hline
\end{tabular}

Source: Report, 'The Economic and Political Climate of Opinion', Box 216, NSF, JFKL.

Notes: $†$ Overlap Coefficient: Overlap $(\mathrm{X}, \mathrm{Y})=|\mathrm{X} \cap \mathrm{Y}| / \min (|\mathrm{X}|,|\mathrm{Y}|)$; * No overlap between 'no opinion' or 'don't care' respondents in the variables considered; ${ }^{* *}$ Complete overlap between 'no opinion' or 'don't care' respondents in the variables considered.

Additional evidence also strengths this conclusion. One finds similar trends looking at other public opinion surveys organized by the USIA in Brazil in the early 1960s. In January 1961, for example, a survey conducted in the country's greatest urban areas (the cities of Rio de Janeiro, São Paulo, Porto Alegre, Belo Horizonte, and Recife) found out that $61 \%$ of all respondents supported agrarian reform, while $39 \%$ thought Brazil should pursue a neutralist foreign approach (28\% and $24 \%$ did not have opinion, respectively). In this case, the overlap coefficient ranges from zero (worst-case) to 0.61 (best-case). Despite the more limited geographical scope of this survey, it is highly significant the fact that, even before Goulart came into power - bringing over proposals for agrarian reform, and intensifying the country's Independent Foreign Policy - there was already a significant support for both policies in Brazil's greatest urban areas. ${ }^{8}$

\section{Conclusions}

Brazil's public opinion in the Goulart administration (1961-1964), at least when it comes to urban centers and to the 1961-1962 period, presented some degree of coherence regarding domestic and foreign issues. Overall, this matches the recent conclusions brought out by the literature on the evolution of public opinion in developed democracies, particularly in the United States. The 1962 survey poll conducted by the INESE on behalf of the USIA suggests that Brazilians sponsored a reformist position domestically and, to a lesser extent, argued for an autonomist position in the international arena. Despite the lack of the survey's microdata, we argued that it is reasonable to expect that a large number of Brazilians reformist also stood up for an autonomous foreign policy. This finding is supported by three groups of evidences: first, the large overlap coefficients presented by the two major proposals of redistributive reforms (particularly agrarian reform); second, the fact

8 Report, 'P/61 L, Study Opinion on Selected International and National Issues', Jan. 1961, Box 11, CPF, RG 306, NARA. 
that is reasonable to assume that 'no opinion' respondents across domestic and international variables tended to overlap; and, finally, the similar patterns found in other (but less broad) surveys organized by the USIA in early 1960s Brazil.

There are, however, two important constraints in this picture: first, if the trend suggested in the 1961-1962 period is correct (e.g., greater support for agrarian reform and lower support for neutralism), then Brazilians seemed to be heading towards incoherence on the eve of the 1964 military coup. And, second, even though many wanted redistributive reforms, a significant portion wished to implement moderate changes, respecting property rights. This, along with the pragmatic approach brought in by Goulart's Independent Foreign Policy (PEI), might explain why Brazilians who had a good opinion about the United States could also have supported an autonomous foreign approach.

The moderate perspective on domestic reforms and the country's good image of the United States tend to be neglected by the literature on public opinion in Goulart's Brazil. Scholars such as Rodrigo Motta (2014), who have employed Brazil's own survey pools (IBOPE), have argued that Brazilians wanted redistributive reforms in the early 1960s (which is broadly correct), without posing attention, however, to the fact that a significant portion of those who wished for reforms wanted to implement them moderately. At the same time, authors who have looked into Brazilian media and Federal Legislative, such as Mansur (2004), have argued that a strong polarized debate was taking place between those that she labels as "liberal-westerns" (liberais-ocidentalistas) and "national-revisionists" (nacional-revisionistas). According to Mansur, while liberals were strongly anticommunist, pro-market, and in favor of a strict alignment with Washington; nationalists, on the other hand, favored strong redistributive reforms domestically and an autonomous foreign approach in world affairs, pending, however, more to the Soviet bloc than to the United States if it were necessary to choose sides.

As it became clear, our findings show that the Brazilian public opinion presented a very different picture of that portrayed by the country's media and political representatives. Public opinion on foreign policy issues in Goulart's Brazil could well be characterized as polarized, as Mansur suggests, but the relevant polarization seems to have happened not between those that were pro-US and pro-USSR, but those that were pro-Washington and pro-neutralism. Communist countries and communist personalities, such as Fidel Castro, were not well regarded by the Brazilian population in general. If this gulf between public opinion and Brazilian political representatives in the early 1960s were in fact true, then major interesting points are brought into the debate on the reasons behind the fall of Brazil's post-war democracy: why wasn't the country's political system able to tune itself to domestic public opinion? Why have Brazilian politicians and media been incapable of bringing this support for moderate reforms into the fore? Even though these are points that surpass the boundaries of this paper, the answer does not seem to rely on the incoherence of the Brazilian public opinion. 


\section{Bibliographic references}

Abreu, Marcelo de Paiva. The Brazilian Economy, 1930-1980. In The Cambridge History of Latin America, by Leslie Bethell, 283-393, vol. 9. New York: Cambridge University Press, 2008.

Albuquerque, et al. Os impactos da crise financeira sobre a opinião pública brasileira. Revista Brasileira de Comércio Exterior ano 8, no. 58 (1999): 18-20.

Aldrich, John et al. Foreign Policy and the Electoral Connection. Annual Review of Political Science 9 (2006): 477-502.

Aldrich, John et al. Foreign Affairs and Issue Voting: Do Presidential Candidates Waltz Before a Blind Audience? American Political Science Review 83 (1989): 123-141.

Almeida, Maria Hermínia et al. O Brasil, as Américas e o mundo: opinião pública e política externa 2010-2011. São Paulo: IRI-USP, 2012.

Almond, Gabriel. The American People and Foreign Policy. New York: Harcourt Brace, 1950.

Bandeira, Luiz Alberto Moniz. O Governo João Goulart: As Lutas Sociais no Brasil, 1961-1964.

8. São Paulo: UNESP, 2010.

Baum, Matthew, Philip Potter. The Relationships Between Mass Media, Public Opinion, and Foreign Policy: Toward a Theoretical Synthesis. Annual Review of Political Science 11 (2008): 39-65.

Bressian, Regiane. A integração sul-americana e a superação da pobreza: uma abordagem pela percepçao das elites. São Paulo: PhD Dissertation, University of São Paulo, 2012.

Burstein, Paul. The Impact of Public Opinion on Public Policy: A Review and an Agenda. Political Research Quarterly 56, no. 1 (2003): 29-40.

Casaróes, Guilherme. A mídia e a política externa no Brasil de Lula. Austral: Revista Brasileira de Estratégia e Relaçóes Internacionais 1, no. 2 (2012): 211-236.

Castillo, R. et al. To Know or not to Know? Realist and Liberal Theories on Foreign Affairs and Public Opinion in Latin America. Latin America Policy, 6, no. 1 (2015), 2-18.

Culp, Julian, Johannes Plagemann. Hooray for Global Justice? Emerging Democracies in a Multipolar World. GIGA Working Papers, 242 (2013): 1-24.

Delli-Carpini, Michael, Scott Keeter. What Americans Know about Politics and Why It Matters. New Haven, CT: Yale University Press, 1996.

Faria, Carlos Aurélio Pimenta de. O Itamaraty e a política externa brasileira: do insulamento à busca de coordenação dos atores governamentais e de cooperação com os agentes societários. Contexto Internacional 34, no. 1 (2012): 311-355.

Faria, Carlos Aurélio Pimenta de. Opinião pública e política externa: insulamento, politização e reforma na produção da política exterior do Brasil. Revista Brasileira de Política Internacional 51, no. 2 (2008): 80-97.

Feldman, Stanley. Structure and Consistency in Public Opinion: the Role of Core Beliefs and Values. American Journal of Political Science 32, no. 2 (1998): 416-440.

Fenton, Laurence. Palmerston and The Times: Foreign Policy, the Press and Public Opinion in Mid-Victorian Britain. London and New York: I.B. Tauris, 2012. 
Ferreira, Jorge. João Goulart. Uma Biografia. Rio de Janeiro: Civilização Brasileira, 2012.

Ferreira, Jorge, Ângela Maria Gomes. 1964 : O golpe que derrubou um presidente, pôs fim ao regime democrático e instituiu a ditadura militar no Brasil. Rio de Janeiro: Record, 2014.

Gonzalez, Guadalupe, et al. Mexico, the Americas, and the World, 2012-2013. Mexico, D.F.: CIDE, 2013.

Hershberg, James. Quadros, Foreign Aid (and Trade), and the Normalization of BrazilianSoviet-bloc Relations, 1961: The "Itinerant Ambassador" and the Explosion Over Germany. Paper Presented at the Annual Meeting of the Society for Historians of American Foreign Relations (SHAFR), 2015.

Hershberg, James. The United States, Brazil, and the Cuban Missile Crisis, 1962 (Part II). Journal of Cold War Studies 6, no. 3 (2004): 5-67.

Hirst, Mônica. Understanding Brazil-United States Relations. Brasília: Fundação Alexandre de Gusmão, 2013.

Holsti, Ole. Public Opinion and American Foreign Policy. Ann Arbor: University of Michigan Press, 2004.

Holsti, Ole. Public Opinion and Foreign Policy: Challenges to the Almond-Lippmann Consensus Mershon Series: Research Programs and Debates. International Studies Quarterly 36, no. 4 (1992): 439-466.

Holzhacker, Denilze. Atitudes e Percepçôes das Elites e População sobre a Política Externa Brasileira nos anos 90. São Paulo: PhD Dissertation, University of São Paulo, 2006.

Hurwitz, Jon, Mark Peffley. How Are Foreign Policy Attitudes Structured? A Hierarchical Model. The American Political Science Review 81, no. 4 (1987): 1099-1120.

Hurwitz, Jon, Mark Peffley. Public Images of the Soviet Union: The Impact on Foreign Policy Attitudes. The Journal of Politics 52, no 1 (1990): 3-28.

Iyengar, Shanto, Donald Kinder. News That Matters. Chicago: University of Chicago Press, 1987.

Jacobs, Lawrence, Robert Shapiro. Politicians Don't Pander: Political Manipulation and the Loss of Democratic Responsiveness. Chicago: University of Chicago Press, 2000.

Kapur, Devesh. Public Opinion and Indian Foreign Policy. India Review 8, no. 3 (2009): 286-305.

Kennedy, Ryan, Matt Dickenson. Turkish Foreign Policy and Public Opinion in the AKP Era. Foreign Policy Analysis 9, no. 2 (2012): 171-188.

Krosnick, Jon, Donald Kinder. Altering the Foundations of Support for the President Through Priming. American Political Science Review 84, no. 2 (1990): 497-512.

Kull, Steven. Opportunities for Bipartisan Consensus - What Both Republicans and Democrats Want in US Foreign Policy. World Public Opinion Report, 2007: 1-31.

Kusnitz, Leonard. Public Opinion and Foreign Policy: America's China Policy, 1949-1979. Westport, CT: Greenwood Press, 1984.

Labaki, Almir. A crise da renúncia e a solução parlamentarista. São Paulo: Brasiliense, 1986.

Lessa, Mônica, Leandro Gavião. Política externa, mídia e propaganda nos governos Lula da Silva (2003-2010). In A politica externa brasileira na Era Lula: um balanço, by Adriano Freixo et al. Rio de Janeiro: Apicuri, 2011. 
Lima, Maria Regina. A Política Externa Brasileira e os Desafios Sul-Sul. Revista Brasileira de Politica Internacional 48, no. 1 (2005): 24-59.

Lima, Maria Regina. Ejes analíticos y conflicto de paradigmas en la política exterior brasileña. América Latina Internacional 1 (1994): 27-46.

Loureiro, Felipe. Empresários, Trabalhadores e Grupos de Interesse: a Politica Econômica nos Governos Jânio Quadros e João Goulart (1961-1964). São Paulo: PhD Dissertation, University of São Paulo, 2012.

Loureiro, Felipe. The Alliance For or Against Progress? US-Brazilian Financial Relations in the Early 1960s. Journal of Latin American Studies 46, no. 2 (2014): 323-351.

Loureiro, Felipe. Strikes in Brazil during the Government of João Goulart. Candian Journal of Latin American and Caribbean Studies. Forthcoming (2016).

Lowi, Theodore J. Four Systems of Policy, Politics, and Choice. Public Administration Review 32, no 4 (1972): 298-310.

Maggiotto, Michael, e Eugene Wittkopf. American Public Attitudes Toward Foreign Policy. International Studies Quarterly 25, no. 4 (1981): 601-631.

Manzur, Tânia. Opinião Pública e Política Exterior do Brasil (1961-1964). Curitiba: Juruá, 2009.

Manzur, Tânia. Opinião pública e política externa do Brasil do Império a João Goulart: um balanço historiográfico. Revista Brasileira de Política Internacional 42, no. 1 (1999): 30-61.

Motta, Rodrigo Patto Sá. O golpe de 1964 e a ditadura nas pesquisas de opiniāo. Revista Tempo 20 (2014): 1-21.

Nau, Henry, Matthew Baum. Foreign Policy Worldviews and US Standing in the World. APSA 2012 Annual Meeting Paper (2012).

Page, Benjamin, Marshall Bouton. The Foreign Policy Disconnect: What Americans Want from Our Leaders But Don't Get. Chicago: University of Chicago Press, 2006.

Page, Benjamin, Robert Shapiro. The Rational Public: Fifty Years of Trends in American Policy. Chicago: University of Chicago Press, 1992.

Popkin, Samuel. The Reasoning Voter. New York: University of Chicago Press, 1994.

Rabe, Stephen G. The Killing Zone. The United States Wages War on Latin America. 1. New York: Oxford University Press, 2012.

Reis Filho, Daniel Aarão. Ditadura e democracia no Brasil: do golpe de 1964 à Constituição de 1988. Rio de Janeiro: Zahar, 2014.

Resende, Carlos Augusto. Politica Externa Independente: as relaçôes com os Estados Unidos na busca por autonomia. Brasília: PhD Dissertation, University of Brasília, 2009.

Saes, Alexandre, Felipe Loureiro. What developing countries' past energy policies can tell us about energy issues today? Lessons from the expropriation of American Foreign and Power in Brazil (1959-1965). Utilities Policy 29 (2014): 36-43.

Skidmore, Thomas. Politics in Brazil, 1930-1964: An Experiment in Democracy. Oxford New York: Oxford University Press, 2007. 
Sniderman, Paul. The New Look in Public Opinion Research. In Political Science: The State of the Discipline, by A. W. Finifter, 219-46. Washington, D.C.: American Political Science Association, 1993.

Souza, Amaury. A Agenda Internacional do Brasil: um estudo sobre a comunidade brasileira de política externa. Rio de Janeiro: Centro Brasileiro de Relaçóes Internacionais, 2002.

Souza, Amaury. O Brasil na Região e no Mundo: Percepçóes da Comunidade Brasileira de Política Externa. Rio de Janeiro: Centro Brasileiro de Relaçóes Internacionais, 2008.

Storrs, Keith. Brazil's Independent Foreign Policy, 1961-1964: Background, Tenets, Linkage to Domestic Politics, and Aftermath. Ithaca, NY: PhD Dissertation, Cornell University, 1973.

Thompson, J. M. The Impact of Public Opinion on Theodore Roosevelt's Foreign Policy. Cambridge, UK: PhD Dissertation, University of Cambridge, 2010.

Verba, Sidney et al. Public Opinion and the War in Vietnam. American Political Science Review 61 (1967): 317-33.

Vigeviani, Tullo, Gabriel Cepaluni. A política externa de Lula da Silva: a estratégia da autonomia pela diversificaçáo. Contexto Internacional 29, no. 2 (2007): 273-335.

Vizentini, Paulo Fagundes. Relaçóes Internacionais e Desenvolvimento: o Nacionalismo e a Política Externa Independente, 1951-1964. Petrópolis: Vozes, 1995.

Wattles, Marshall. Literacy and Development in Latin America. Paris, UNESCO/EAO, (1966): 1-16.

Weis, Michael. The Twilight of Pan-Americanism: The Alliance for Progress, Neo-Colonialism, and Non-Alignment in Brazil, 1961-1964. The International History Review 23, no. 2 (2001): 322-344.

Welch, Cliff. The Seed Was Planted. The São Paulo Roots of Brazil's Rural Labor Movement, 1924-1964. University Park: The Pennsylvania State University Press, 1999.

Whitehead, Laurence. Emerging Market Democracies: East Asia and Latin America. Baltimore and London: The John Hopkins University Press, 2002.

Wilkinson, S. Perceptions of Public Opinion. British Foreign Policy Decisions About Nazi Germany, 1933-1938. Oxford: PhD Dissertation, University of Oxford, 2000.

Zaller, John. The Nature and Origins of Mass Opinion. Cambridge, UK: Cambridge University Press, 1992.

\section{Acknowledgements}

This research has been funded by Fundação de Amparo à Pesquisa do Estado de São Paulo (FAPESP). We thank Denise Holzhacker, Fernando Mourón, two anonymous reviewers of the $R B P I$, and seminar participants at the Institute of International Relations of the University of São Paulo for their valuable comments and suggestions. Faults and limitations are our responsibility. 


\section{Abstract}

This paper analyses public opinion during the João Goulart government in Brazil (1961-1964), focusing on public perceptions on domestic and foreign policies. We employ a recently declassified public opinion survey conducted on behalf of United States Information Agency (USIA) in urban areas. We found that the Brazilian public opinion was somewhat coherent, supporting redistributive reforms domestically and a neutralist approach in foreign affairs.

Keywords: Brazilian Foreign Policy; João Goulart's administration; Public Opinion; Domestic issues in Brazil.

\section{Resumo}

O artigo analisa a opinião pública durante o governo de João Goulart no Brasil (1961-1964), focando nas percepções sobre políticas nacional e internacional. Emprega-se uma pesquisa de opinião pública recentemente liberada feita a pedido da United States Information Agency (USIA) em áreas urbanas. Conclui-se que a opinião pública era razoavelmente coerente, apoiando reformas domésticas distributivas e uma abordagem neutralista em questões internacionais.

Palavras-chave: Política Externa Brasileira; Governo João Goulart; Opinião Pública; Assuntos domésticos no Brasil;

Received: September 29, 2015

Accepted: November 30, 2015 